\title{
ANALYSIS OF THE INFLUENCE OF WAVES IN THE OCCURRENCE OF ACCIDENTS IN THE PORTUGUESE COAST USING BAYESIAN BELIEF NETWORKS
}

\section{WPLYW FAL NA WYSTĘPOWANIE WYPADKÓW W STREFIE BRZEGOWEJ PORTUGALII - ANALIZA Z WYKORZYSTANIEM SIECI BAYESOWSKICH}

\author{
Pedro Antão ${ }^{(1)}$, C. Guedes Soares ${ }^{(2)}$
}

Centre for Marine Technology and Engineering (CENTEC),Technical University of Lisbon Instituto Superior Técnico, Av. Rovisco Pais, 1049-001 Lisbon, Portugal Emails: ${ }^{(1)}$ pantao@mar.ist.utl.pt, ${ }^{(2)}$ guedess@mar.ist.utl.pt

Abstract: Sea and weather conditions are the second most frequent cause of accidents in Portuguese waters accounting for 23\% of the occurrences. However due to lack of information in the Portuguese maritime accident database it is difficult to assess what this cause consists specifically, i.e., fog, large wave heights or other events. In the present study significant wave height data was introduced in a Bayesian Belief Network (BBN) model in order assess the correlation between their amplitude and certain accident typologies and related consequences (human injuries or fatalities). The results of different inferences of the BBN model show that through a simple modification of an accident model the influence of weather pattern can be assessed and specific risk factors can be identified.

Keywords: Bayesian Belief Networks, maritime accidents, significant wave height

Streszczenie: Stan morza $i$ warunki atmosferyczne to druga z najczęściej występujacych przyczyn wypadków na wodach terytorialnych Portugalii, odpowiedzialna za 23\% zdarzeń. Ze względu na brak informacji w bazie danych o wypadkach morskich w Portugalii trudno jednak ocenić, co konkretnie stanowi o zaistnieniu wypadku: mgła, duża wysokość fal, czy też inne czynniki. W niniejszej pracy dokonano nastepujacego zabiegu: do modelu opartego na sieci bayesowskiej (Bayesian Belief Network - BBN) wprowadzono dane o znaczacej wysokości fal, a to celem dokonania oceny korelacji między ich amplituda, typologia wypadków określonego rodzaju, oraz wynikajacymi konsekwencjami w postaci odniesionych przez ludzi obrażeń czy też wypadków śmiertelnych. Wyniki wnioskowania na bazie modelu BBN dowodza, że dzięki prostej modyfikacji modelu wypadku można ocenić wplyw określonych warunków atmosferycznych na zaistnienie wypadku oraz zidentyfikować konkretne czynniki ryzyka.

Stowa kluczowe: sieci bayesowskie, wypadki morskie, znaczaca wysokość fali 


\section{Introduction}

Accidents classified as a result of bad weather conditions are largely dependent on the accuracy of the information gathered after the occurrence, i.e., position of accident, significant wave height, existence of fog, etc., information which depends on the accident investigation procedure and subsequent data analysis. As reported in earlier studies, accidents identified explicitly as being related with bad weather conditions represent roughly $3 \%$ of the overall accidents (Guedes Soares et al., 2001).

This low value of weather related occurrences can be related to poor or inadequate accident reporting schemes or due to the characteristics of the geographical areas where the accidents occurred. Portugal is no exception in both of these issues, i.e., the accident reporting scheme is does not specify details concerning the influence of weather on the occurrences, and the Portuguese coast presents characteristics that lead to frequent occurrences due to the existence of rough seas.

These characteristics have been already identified in the work of Gouveia et al. (2007) where a statistical analysis of ship accidents in the Portuguese waters was performed. In that study the 857 records of the Portuguese Maritime Authority database were used to identify the main accident typologies. In it high frequency of some type of accidents as is the case of the 26 founderings, 21 groundings or 5 collisions per year were identified. Similarly the main causes of the registered accidents were mainly material failure $(25 \%)$, sea and weather (23\%) and human error $(18 \%)$.

Recently Bayesian Belief Networks (BBN) have been used in the maritime industry with the development of specific models to assess and identify risk factors associated to a given context (Eleye-Datubo et. al., 2006; Trucco et. al., 2006; Norrington et. al., 2008). In the present study a BBN model for maritime accidents developed by Antão et. al. (2008) is used with the inclusion of wave data (significant wave heights) in order to assess the correlation between their amplitude and certain accident typologies and related consequences (human injuries or fatalities). In order to reduce the uncertainty only numerical data were used. For the real data the Portuguese Maritime Authority accident database mentioned above was used together with the HIPOCAS and NCEP/NOAA wave data were used.

\section{BBN Model Including Wave Height Data}

As mentioned, $23 \%$ of the causes of the accidents were sea and weather which is the second most frequent cause of occurrences. However, since no additional details are provided in the database, it is difficult to assess in 
what consists specifically this cause, i.e., fog, high currents, large wave heights, wave steepness or other events. Earlier studies have shown that ship accidents reported as due to bad weather conditions occurred in areas also with highest expected significant wave height or highest mean wave steepness occurrence (Guedes Soares et. al., 2001, Bitner-Gregersen and Guedes Soares, 2007).

In many cases accidents associated with the occurrence of bad weather conditions are also linked with situations where crews present a low risk perception or a high risk acceptance, particularly in the cases of recreation and fishing activities respectively. In the latter, these risky behaviours are a consequence of social-economical factors, as there is a continuous effort to earn higher wages, which are proportional to the amount of fish captured (Antão et. al., 2008). Therefore, in this study additional data of wave height will be introduced in a BBN model in order to assess the contribution that large waves had in the occurrence of certain accident typologies.

In order to fulfil this objective HIPOCAS wave database (Pilar et al 2008) and the NCEP/NOAA (National Centers for Environmental Prediction/National Oceanic and Atmospheric Administration) wave data were used. The need of using two sources of data was due to the fact that HIPOCAS only covered the period until 2001, whereas the NCEP/NOAA covered the remaining period of the accident sample (i.e., 2004-2006).

The HIPOCAS was an EU project aiming at producing a 40 years hindcast of wind, wave, sea level and current climatology for European waters (Guedes Soares 2008). The predictions were made with a typical horizontal resolution of $25-\mathrm{km}$ and temporal resolution of 3 hours. The wave hindcasts were validated by comparisons with wave data buoy measurements when available.

In Fig. 1 shows the HIPOCAS grid with the location of the accidents. As one may see there are three different resolutions of the grid, where the finer one located near the Portuguese coast, Azores and Canary Isles is a grid of $0,25^{\circ}$; a second one is a grid resolution of $0,5^{\circ}$ and a third one, located in longitudes above $\mathrm{W} 33$, is a grid of $1^{\circ}$. However, in many cases there was a mismatch between the accident location and the grid points. The option adopted in these cases was to use the nearest grid point data. Most of the accidents are located near coastal areas, and therefore, in the higher resolution grid (the exception is Madeira), what allowed to have a good match and an adequate input. 


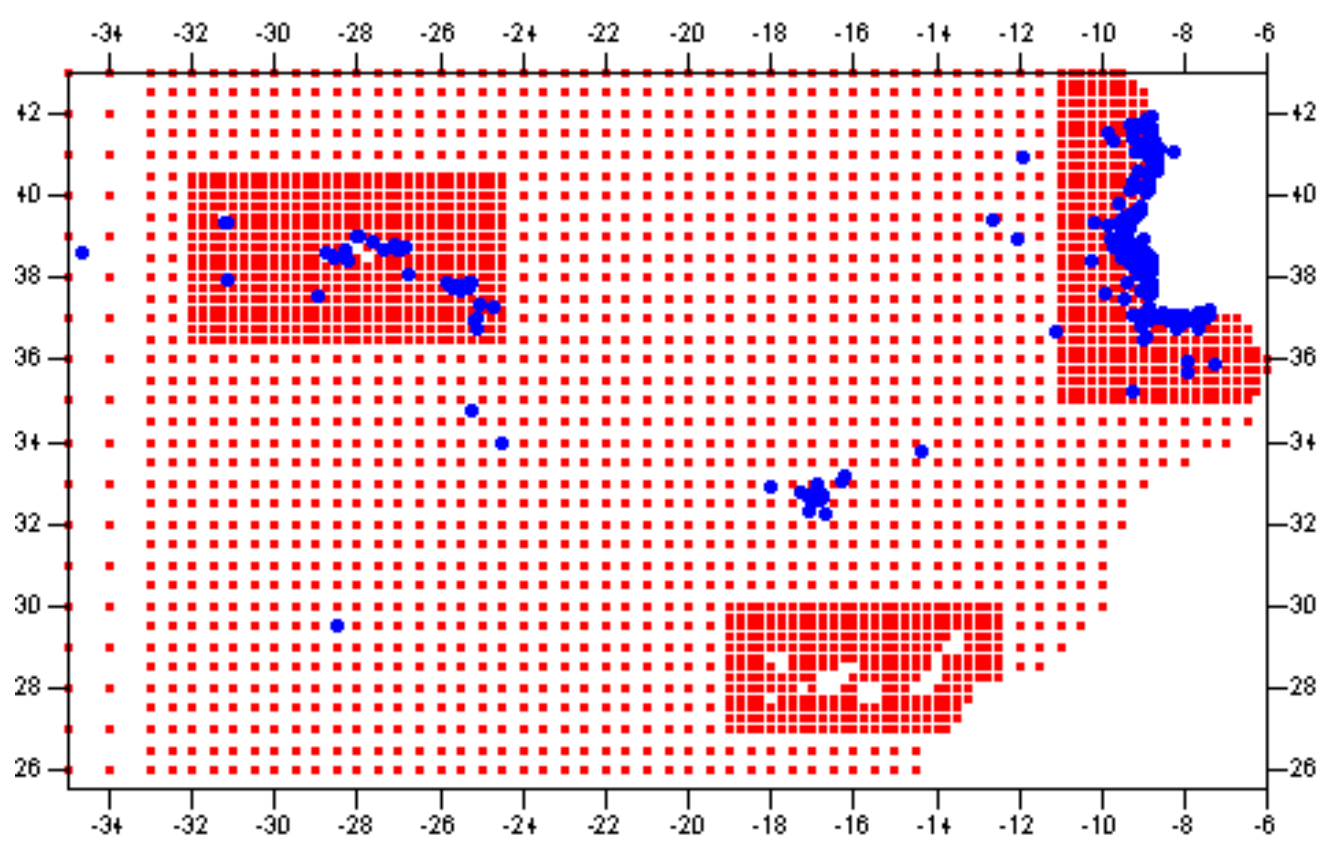

Fig. 1 Accidents location in HIPOCAS spatial grid

In the case of the NCEP/NOAA, the data is divided in a coverage (longitude, latitude) grid between $77^{\circ} \mathrm{S}-77^{\circ} \mathrm{N}$ of resolution $1.25^{\circ} \times 1^{\circ}$ degrees. This data, also presents a temporal resolution of 3 hours and ranges from 1999 until the present date. Due to the fact that the two sources present similar grids (in the higher resolutions) and use a comparable wave prediction model, it was possible to integrate both data within the model. Given these data sources, the specific significant wave heights on the ship accidents locations were identified.

For each accident the nearest position on the grids was chosen for each of the accident locations since very rarely the real position coincided with the grid one. Also, in case of equal distances between an accident position and two grid points, the preference to the grid points which present the nearest longitude to the accident one was given. This criterion was chosen in order to avoid potential influence of shallow water on $\mathrm{Hs}$ values in longitudes near to the coast. Waves generated by wind (wind waves) present primarily periods of 3 to $25 \mathrm{sec}$. and are a fundamental feature of coastal regions of the world (US Army Manuals, 2003). 
If one considers the range of periods mentioned and the wave length given by:

$$
L=\frac{g T^{2}}{2 \pi}
$$

where $d$ is the water depth, $L$ is the wave length and $T$ is the wave period, from the criterion for deep water $(\mathrm{d}>\mathrm{L} / 2)$ it results that deep water starts at depth more or less of $500 \mathrm{~m}$ (if one considers the upper limit of the wave period mentioned above). In fact if the results of Fig. 2 are compared with the ones located at $-8.75 \mathrm{~W}, 37 \mathrm{~N}$, which is situated near the south Portuguese coast, a average difference of $30 \%$ on the significant wave height could be found, and a maximum of 55\% of difference for the month of March.

These were expected results, although in both sites there are deep water conditions but the fundamental difference is that the second location is sheltered by the European coast while the other one is far in the open ocean where stronger winds can achieve great velocities on large distances generating waves higher than the ones measured near Europe.

Additionally the height of the locally generated wind waves is increased by the superposition of the swell coming from all directions, while the site near Western Europe coast has swell coming mainly just from western and southern part of the Atlantic Ocean.

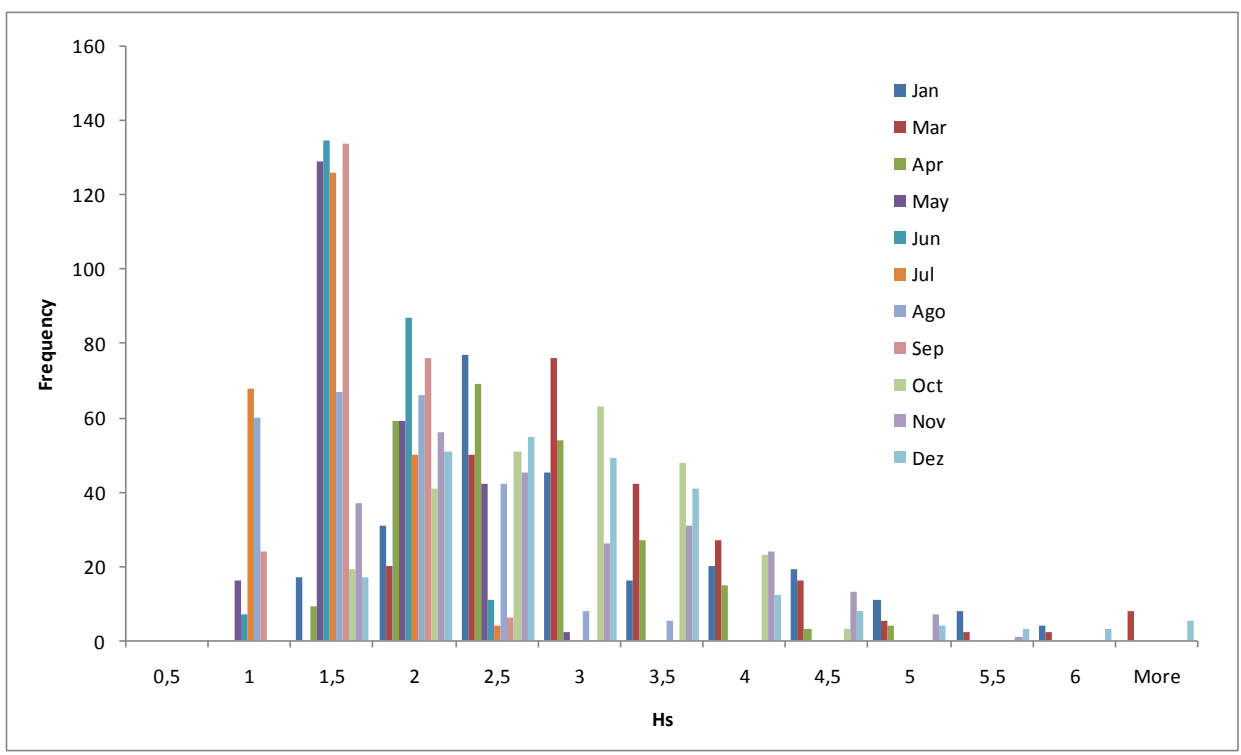

Fig. 2 Wave height distribution for the year of 2004, location in $-25 \mathrm{~W}, 35 \mathrm{~N}$ 

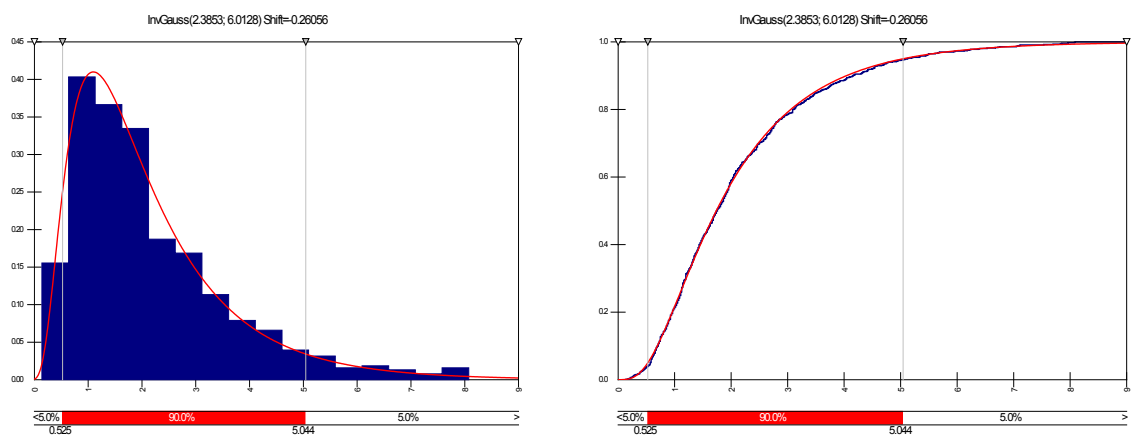

Fig. 3 Density and cumulative distribution functions for the $\varepsilon$ values of $H$ s in all the accident locations

As mentioned before, for each of the accidents, where the location was known $(\mathrm{N}=765)$, the estimated value was identified. Figure 3 presents respectively the density and cumulative distribution functions for the $\varepsilon$ values in the accident locations, in which one may see a positive skewness as a result of the existence of large significant wave height (above 6 meters).

Fig. 4 shows the updated version of the BBN model presented in Antão et al. (2008) with the addition of the wave height node. The significant wave height is highly dependent on the hour and month nodes, as a result of alterations in the wave statistics with the season.

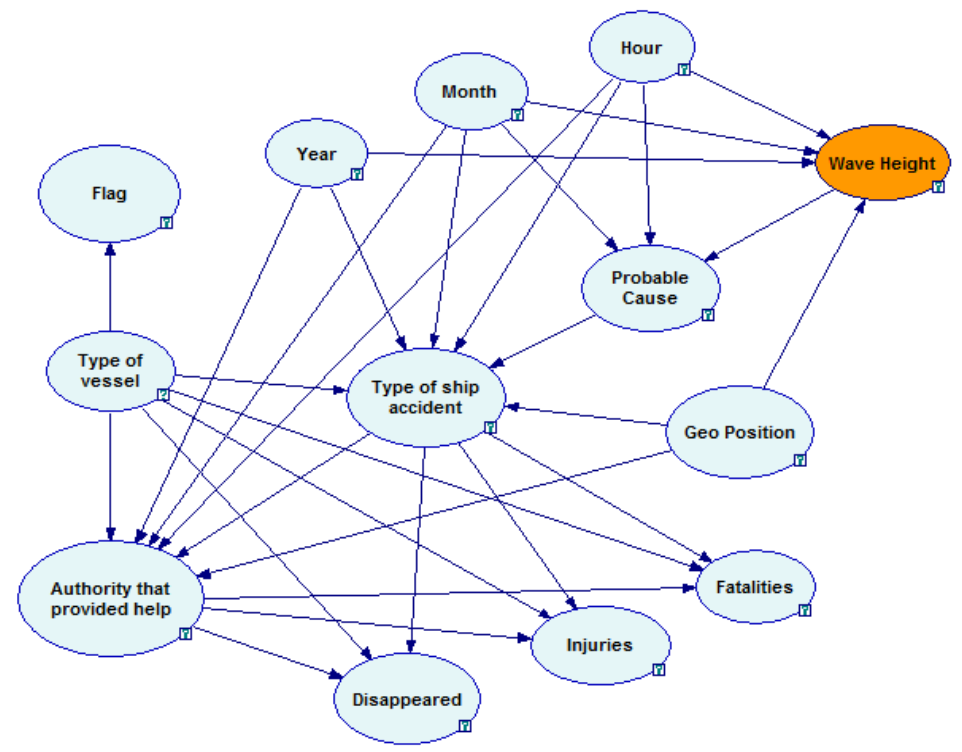

Fig. 4 BBN model with wave height node 


\section{Results and discussion}

Based on the model of Fig. 4 a set of inferences were performed and are presented in this chapter. Although the above model can be considered as simple due to the number of nodes involved it should be mentioned that the number of states involved per node are large, ranging from 4 states, in the fatalities node, up to 31 states in the Geo Position and Flag ones. As mentioned above the Conditional Probability Tables (CPT) for each node is the result of real and numerical data with no expert opinion involved. In fact due to the substantial number of combinations in each node it wouldn't be possible to use expert opinion to populate the CPT's.

Fig. 5 shows the probability of a fatality for different ship and accident types, when the main cause of the occurrence was sea and weather and with small significant wave heights ( $\mathrm{Hs}=0$ to $2 \mathrm{~m}$ ). In these conditions capsize is the occurrence that can lead to higher number of fatalities with fishing vessels.

This result could be surprising due to the fact that the height of the waves involved are small, however it is common practice to see fishing vessels operating near coastal areas and specifically in wave breaking zones, involved in seabass fishing, which lead to frequent accident of this nature.

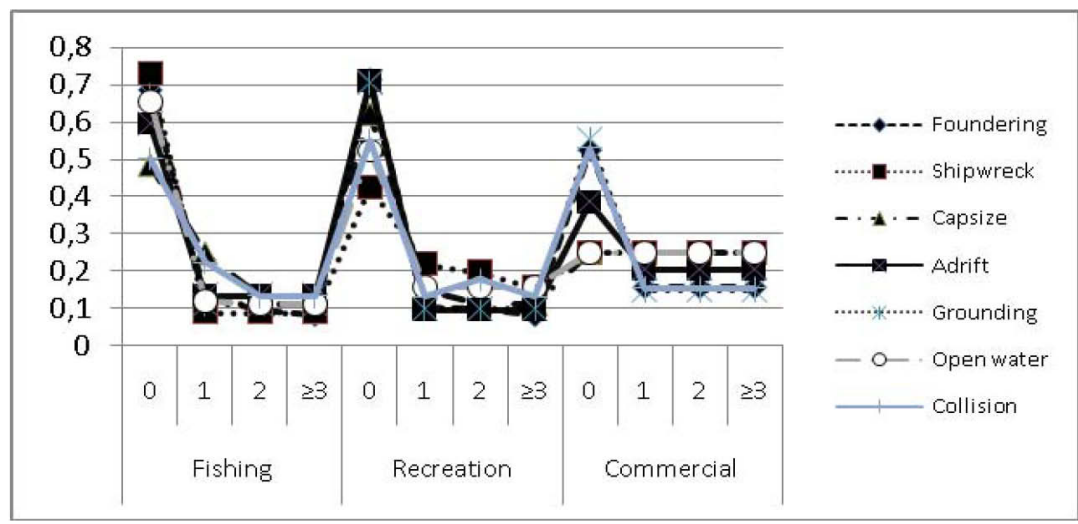

Fig. 5 Probability of fatalities $\mid$ type of accident $=\varepsilon$, type of vessel $=\varepsilon$, cause $=$ sea and weather, $H_{s}=0-2 \mathrm{~m}$

Also collision presents high probability of leading to a single fatality. In the case recreation vessels, high consequences are mainly related to shipwreck and collision occurrences. Commercial vessels don't present so significant variation when compared with the previous two. This can be explained by the low number of accidents $(n=44)$ with these types of vessels in the period of analysis. 
When a comparison is performed between the two most representative ship types in two significant wave heights conditions (Fig. 6) one may see that variations are slightly more evident. In the case of recreation vessels when the significant wave heights are equal to $4-6 \mathrm{~m}$, there is a decrease on the probability of no fatalities due to capsize of $9 \%$ whereas the likelihood of a single fatality increases $5 \%$.

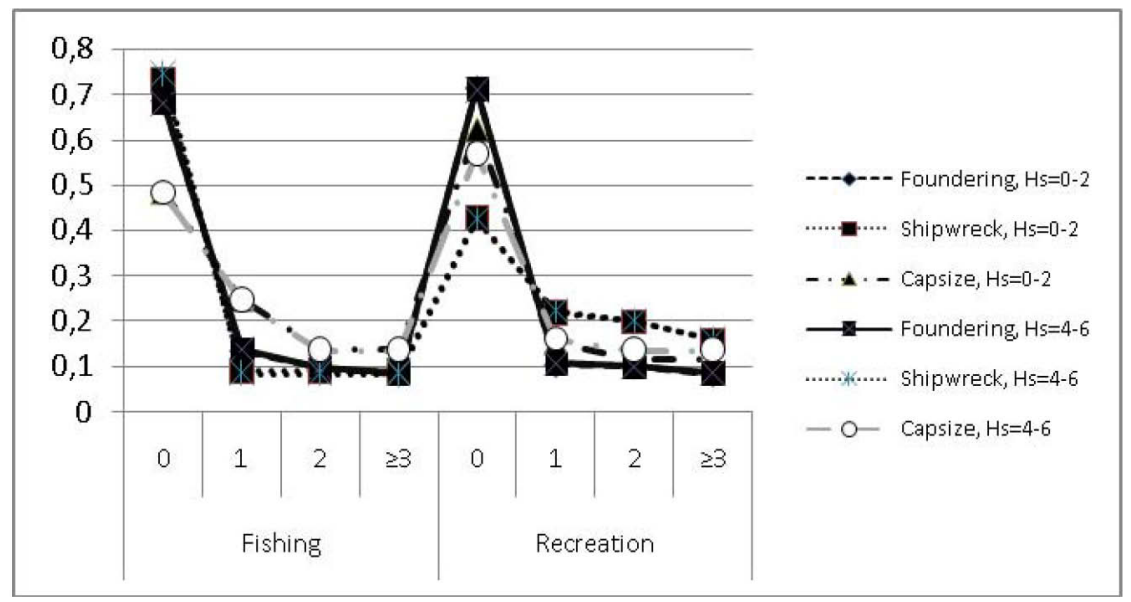

Fig. 6 Probability offatalities $\mid$ type of accident $=\varepsilon$, type of vessel $=\varepsilon$, cause = sea and weather, $H_{s}=0-2 \mathrm{~m}$ and 4-6 $\mathrm{m}$

The influence of these high waves in the case of fishing vessels is not so evident with small variations on the different accident types. These results can be explained by the fact that the operation with recreation vessels is seasonal and in many cases operated by inexperienced personnel leading to low risk perception in given situations, particularly in the presence of high significant wave heights.

Fig. 7 presents the probability of a given type of accident for different months and causes, with small significant wave heights. The fact that a particular accident cause was "coded" as a human factor or material failure doesn't imply that sea and weather didn't play a role in the occurrence.

Significant differences can be found particularly in the periods of May July and November -December. If the first of these periods corresponds to a time with high levels of traffic and therefore with higher probability of occurrences (groundings and capsizes) mainly as a result of material failures causes (much associated with recreation vessels), in the second period one may see that the causes are mainly a result of human errors. In 
this figure one may see also the low influence of weather patterns (sea and weather cause) in the occurrence.

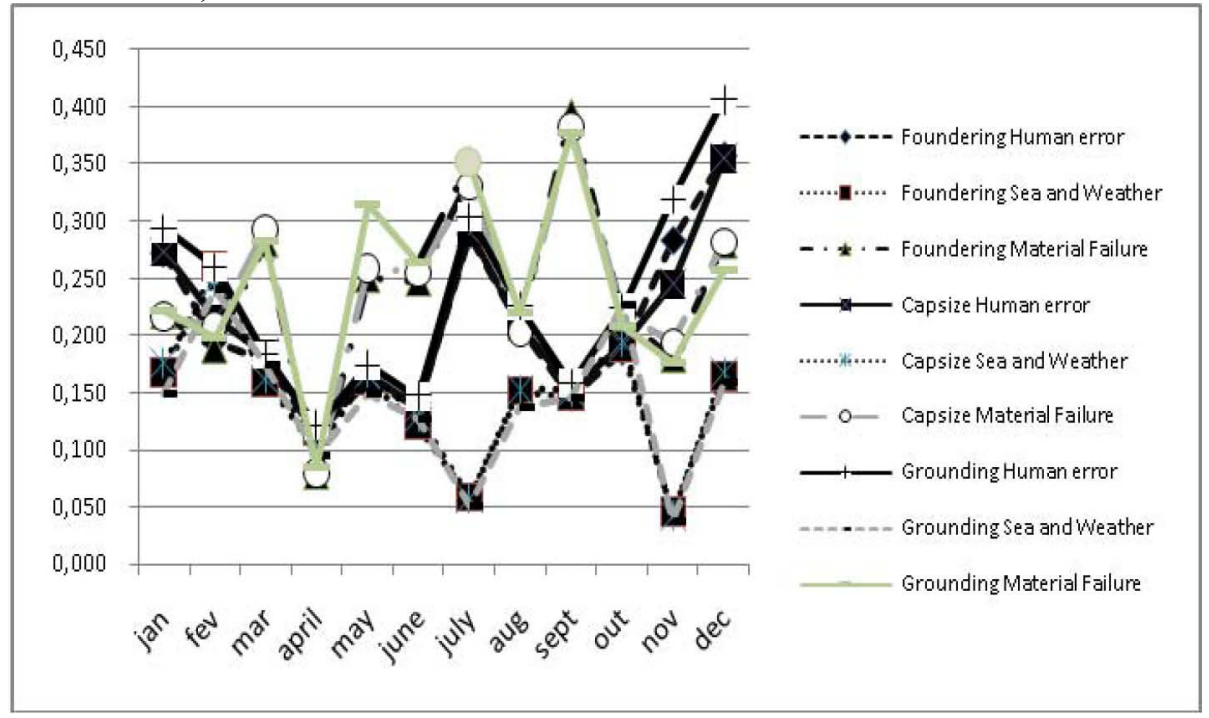

Fig. 7 Probability of type of accident $\mid$ month $=\varepsilon$, type of cause $=\varepsilon, H s=0-2 \mathrm{~m}$

However, when one compares the probabilities for capsize with small and large significant wave heights (Fig. 8) considerable differences can be found. Similarly to the previous figure two periods can be identified where the impact of the large significant wave heights $(4-6 \mathrm{~m})$ leads to a higher probability of capsize. These periods (February-March and SeptemberNovember) present probabilities 3 to 13 times higher than the ones with small significant wave heights $(0-2 \mathrm{~m})$.

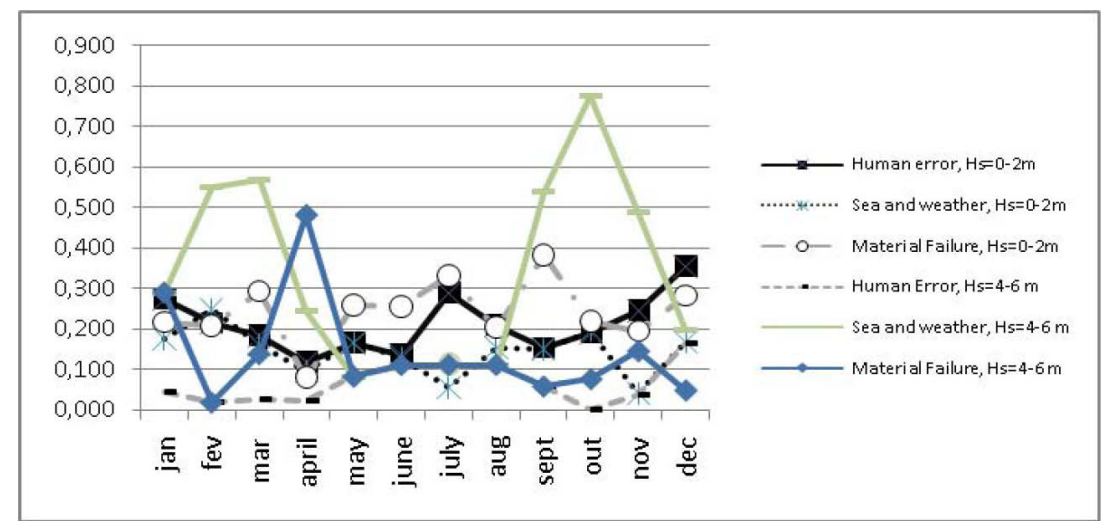

Fig. 8 Probability of type of cause $\mid$ month $=\varepsilon$, type of accident $=$ capsize,

$$
H_{s}=0-2 \mathrm{~m} \text { and } H_{s}=4-6 \mathrm{~m}
$$




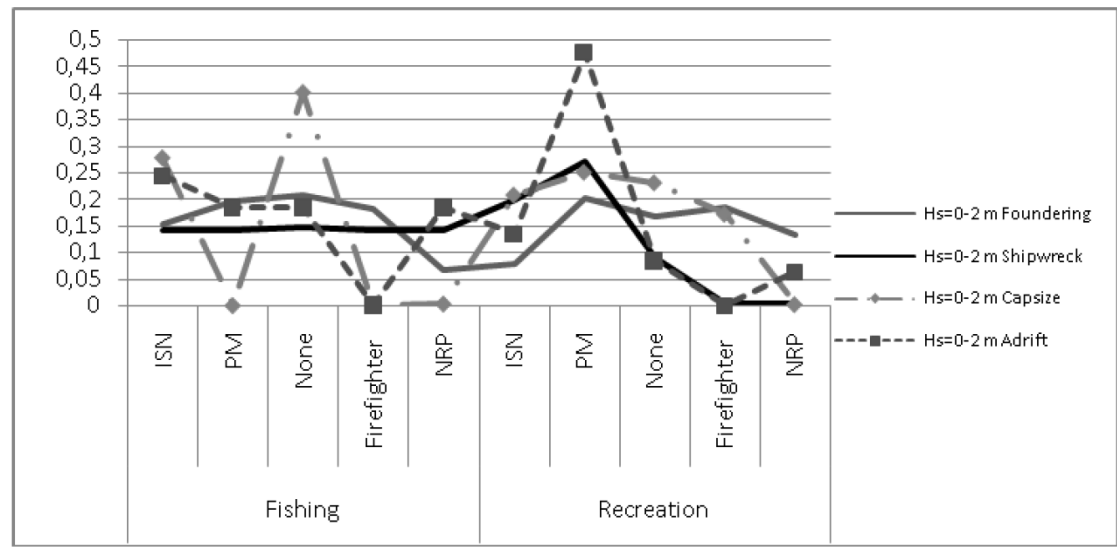

Fig. 9 Probability of authority involved in the rescue $\mid$ fatalities $=$ injuries $=$ disappeared $=0$, type of accident $=\varepsilon$, Geographical position $=$ Lisbon, $H s=0-2 \mathrm{~m}$

Similar analysis was performed to identify the authority involved in the rescue in case of an occurrence in different weather conditions (Fig. 9) and (Fig. 10). Typically the authorities involved in these operations are the Portuguese Navy Vessels (NRP), Maritime Police (PM), to the National Institute to Help Castaways (ISN), Fire-fighters or simple none.

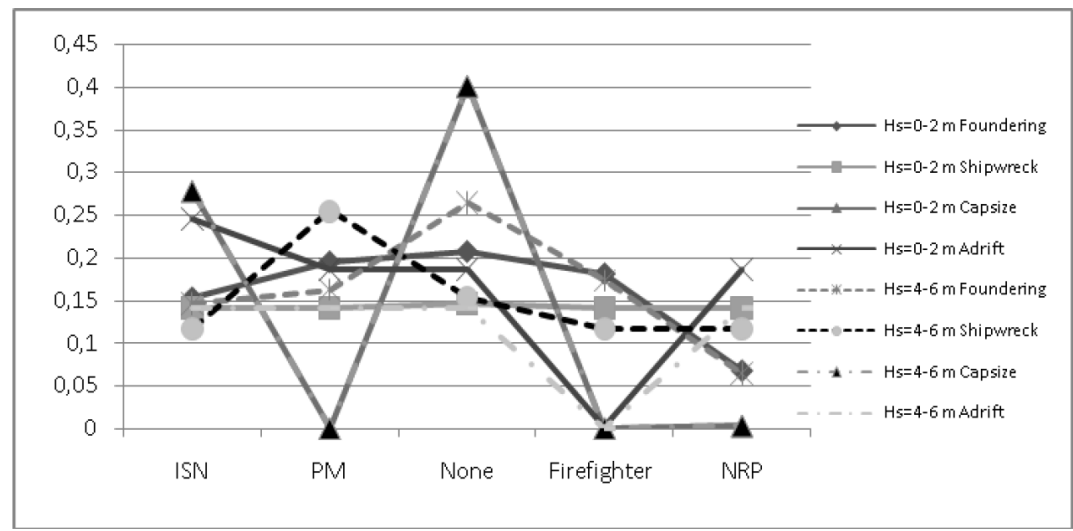

Fig. 10 Probability of authority involved in the rescue $\mid$ fatalities $=$ injuries $=$ disappeared $=0$, type of accident $=\varepsilon$, Geographical position $=$ Lisbon, $H s=0-2 \mathrm{~m}$ and $H_{s}=4-6 m$, Type of vessel= Fishing

It is interesting to notice that the probability that one of these authorities was involved in a rescue decreases with the increase of the significant wave heights, with few exceptions (the role of the $P M$ increases in shipwreck 
accidents) and a substantial increase of none authorities involved. These facts can lead to the conclusion that the means at the disposable of these authorities are limited and in some cases not located in areas with higher probabilities of being needed.

\section{Conclusions}

In the present study the significant wave height data was introduced in a BBN accident model in order assess the correlation between their amplitude and certain accident typologies as well as related consequences (human injuries or fatalities). Results show that large significant wave weights are linked with the occurrence of specific accident types as well as with a higher probability of their occurrence in particular times of the year. Understanding these and other mechanisms associated with large waves will allow the reduction of the risk associated with operations in these weather conditions, by optimizing the implementation of mitigation measures (both proactive and reactive).

\section{Ackowledgements}

The first author acknowledges the financial support of the Portuguese Foundation for Science and Technology under the contract BD/31272/2006.

\section{References}

1. Antão, P., Almeida, T., Jacinto, C. and Guedes Soares, C., 2008, Causes of Occupational Accidents in the Fishing Sector in Portugal, Safety Science, Vol. 46, Issue 6, pp 885-899

2. Antão, P., Grande, O., Trucco, P. and Guedes Soares, C., 2008, Analysis of maritime accident data with BBN modelling, Safety, Reliability and Risk Analysis - Theory, Methods and Applications, Martorell, S., Guedes Soares, C. \& Barnett, J. (Eds), Balkema, Taylor \& Francis Group, Volume II, pp. 3265-3274.

3. Bitner-Gregersen, E. M. and Guedes Soares, C., 2007, Uncertainty of Average Wave Steepness Prediction from Global Wave Databases, Advancements in Marine Structures, C. Guedes Soares and P. K. Das (Eds.), London - UK, pp. 3-10.

4. Eleye-Datubo, A. G., Wall, A., Saajedi, A. and Wang, J., 2006, Enabling a Powerful Marine and Offshore Decision-Support Solution through Bayesian Network Technique, Risk Analysis, Vol. 26, No. 3, pp: 695-721. 
5. Gouveia, J., Antão, P. and Guedes Soares, C., 2007, Statistical analysis of ship accidents in the Portuguese waters, (in Portuguese), Riscos Públicos e Industriais, C. Guedes Soares, A.P. Teixeira and P. Antão (Eds), Edições Salamandra, Lisboa, Vol. I, pp: 499-516.

6. Guedes Soares, C., Bitner-Gregerson, E.M. and Antão, P., 2001, Analysis of the frequency of ship accidents under severe North Atlantic weather conditions, Proc Conf on Design and Operation for abnormal conditions II, RINA, 6-7 November, London, UK, pp. 221-230

7. Guedes Soares, C. 2008, Hindcast of Dynamic Processes of the Ocean and Coastal Areas of Europe, Coastal Engineering; 55(11):825-826.

8. Norrington, L., Quigley, J., Russell, A. and Van der Meer, R., 2008, Modelling the reliability of search and rescue operations with Bayesian Belief Networks, Reliability Engineering \& System Safety, Volume 93, Issue 7, pp: 940-949.

9. Pilar, P.; Guedes Soares, C., and Carretero, J. C. 2008, 44-Year Wave Hindcast For The North East Atlantic European Coast, Coastal Engineering; 55(11):861-871.

10. Trucco, P., Cagno, E., Grande, O. and Ruggeri, F., 2006, A Bayesian Approach for Integrating Organisational Factors in Risk Analysis: A Case Study in Maritime, Safety and Reliability for Managing Risk, C. Guedes Soares \& E. Zio (Eds.). Balkema, Taylor \& Francis Group, Volume I, pp. 443-450.

11. US Army Manuals, Coastal Engineering Manual - Water Wave Mechanics, $\quad$ http://www.usace.army.mil/inet/usace-docs/engmanuals/em1110-2-1100/PartII/PartII.htm (in 17 February 2010). 